\title{
PEMBERDAYAAN KELOMPOK PEREMPUAN MELALUI PENINGKATAN PRODUK LOKAL DI KECAMATAN SUKARAJA KABUPATEN SELUMA PROVINSI BENGKULU
}

\section{EMPOWERMENT OF WOMAN GROUP THROUGH IMPROVEMENT OF LOCAL PRODUCTS IN SUKARAJA SUB DISTRICT SELUMA DISTRICT OF BENGKULU PROVINCE}

\author{
Oleh: \\ Hesti Nur'aini ${ }^{1)}$, Lina Widawati ${ }^{1)}$, Dewi Suranti ${ }^{2)}$ \\ ${ }^{1)}$ Fakultas Pertanian Universitas Dehasen Bengkulu \\ ${ }^{2)}$ Fakultas Ilmu Komputer Unversitas Dehasen Bengkulu \\ Email: hestinuraini1996@gmail.com
}

\begin{abstract}
Bukit Peninjauan II and Sido Luhur village are located in Sukaraja Sub District Seluma District Bengkulu Province with low economic growth. The community professions of Bukit Peninjauan II and Sido Luhur village are farmers and construction workers, while the majority of women act as housewives or unskilled laborers, resulting in a relatively low level of community welfare. The purpose of this community service activity is to establish a food processing business unit (carrot sticks, sweet potato sticks, ebi macaroni and sweet potato macaroni, and increasing skills and knowledge of woman group members about food processing). The result of this activity is small business in processing of carrot sticks, sweet potato sticks, sweet potato macaroni and ebi macaroni which is managed by Mawar Melati (Bukit Peninjauan II) and Mandiri Jaya (Sido Luhur), with the trademark Mawar Melati and Bintang Rafflesia. In addition to counseling and production process training, team together with partners also make the formation of packaging and labeling design, the provision of assistance of production tools and the application of marketing methods in the form of blogspot and socialization of small industry financial management.
\end{abstract}

Keywords: local product, woman groups, small business

\section{PENDAHULUAN}

Desa Bukit Peninjauan II dan Desa Sido Luhur adalah desa yang terletak di wilayah Kecamatan Sukaraja Kabupaten Seluma Provinsi Bengkulu dengan jarak kurang lebih 25 km dari Kota Bengkulu. Pertumbuhan industri di Desa Bukit Peninjauan II dan Desa Sido Luhur masih sangat minim. Sumber penghasilan masyarakat rata-rata berasal dari kegiatan bertani sawah atau buruh bangunan, yang dilakukan oleh kaum laki-laki, sementara kaum perempuannya mayoritas hanya berperan sebagai ibu tumah tangga atau buruh kasar lainnya. Kondisi ini tentu saja berakibat pada rendahnya tingkat kesejahteraan masyarakat Desa Bukit Peninjauan II dan Desa Sido Luhur tersebut. Dilihat dari kondisi wilayah dan masyarakatnya, sebenarnya Bukit Peninjauan II dan Desa Sido Luhur mempunyai potensi yang sangat baik untuk dikembangkan, khususnya di bidang industri pengolahan pangan. Luasnya lahan pekarangan yang dimiliki oleh hampir seluruh warga, sangat potensial untuk dijadikan lahan penanaman beberapa komoditas seperti singkong, ubi jalar dan lainlain yang bisa dijadikan sebagai bahan baku olahan pangan bernilai ekonomi tinggi. 
Untuk mendukung peningkatan kesejahteraan keluarga, peran serta perempuan bisa memberikan kontribusi yang cukup besar. Beberapa fakta membuktikan bahwa perempuan yang bekerja mempunyai andil yang cukup besar dalam peningkatan perekonomian keluarga (Sofia, 2014; Rachmat, 2017). Hasil survei pendahuluan yang pengusul lakukan, menunjukkan bahwa mayoritas kegiatan perempuan di Desa Bukit Peninjauan II dan Desa Sido Luhur adalah sebagai ibu rumah tangga atau sebagai buruh lepas, yang telah mereka jalani secara turun-temurun. Minimnya produktivitas dan aktivitas ekonomi yang dilakukan oleh kaum perempuan di Desa Bukit Peninjauan II dan Desa Sido Luhur ini disebabkan beberapa faktor antara lain kurangnya pengetahuan dan ketrampilan yang dimiliki, sementara pada dasarnya mereka mempunyai potensi yang cukup besar untuk dikembangkan. Hal ini telah dibuktikan dengan telah dibentuknya beberapa kelompok perempuan oleh PKK desa, di antaranya adalah Kelompok Mawar Melati di Desa Bukit Peninjauan II dan Kelompok Mandiri Jaya di Desa Sidodadi, yang bergerak di bidang pendidikan, keterampilan dan arisan, meskipun aktivitasnya masih belum optimal. Melihat permasalahan tersebut, untuk membantu meningkatkan pemberdayaan perempuan di Desa Bukit Peninjauan II dan Desa Sido Luhur dalam kegiatan produksi, khususnya pengolahan produk pangan, dengan harapan terbentuknya industri kecil guna tercapainya peningkatan tingkat perekonomian keluarga yang berujung pada peningkatan kesejahteraan keluarga dan masyarakat desa, tim pengabdian bersama-sama mitra mengidentifikasi bahwa perlu dilakukannya pembentukan unit usaha dan peningkatan soft skill dan keterampilan di bidang pengolahan pangan bagi para ibu-ibu anggota kelompok perempuan Mawar Melati dan Mandiri Jaya, yang bisa dilakukan melalui pendidikan, pelatihan dan aplikasi program pengabdian kepada masyarakat dalam bentuk Iptek bagi Masyarakat (IbM).

Berdasarkan analisis situasi dan survei yang telah dilakukan, pengusul bersamasama mitra menyepakati beberapa masalah yang dihadapi oleh mitra antara lain perlunya upaya pemberdayaan perempuan di Desa Bukit Peninjauan II dan Desa Sido Luhur, guna peningkatan kesejahteraan dan perekonomian keluarga. Tujuan kegiatan pengabdian kepada masyarakat ini adalah untuk membentuk industri kecil yang bergerak di bidang olahan pangan sederhana, yaitu makanan ringan stik wortel, stik ubi ungu, makaroni ebi dan makaroni ubi, yang dikelola oleh kelompok perempuan di Bukit Peninjauan II dan Desa Sido Luhur, yakni kelompok Mawar Melati dan Mandiri Jaya.

\section{METODE PENGABDIAN}

Kegiatan pengabdian kepada masyarakat ini dilaksanakan pada bulan Februari Agustus 2017, berlokasi di Desa Bukit Peninjauan II dan Desa Sido Luhur Kecamatan Sukaraja Kabupaten Seluma Provinsi Bengkulu. Pelaksanaan kegiatan dilakukan mulai dari teknologi pengolahan, pengemasan hingga metode pemasaran yang efektif, dengan tahapan sebagai berikut:

a. Tahap Persiapan, meliputi:

1) Survei, pemantapan dan penentuan lokasi, sasaran serta penentuan permasalahan yang dihadapi oleh mitra.

2) Evaluasi permasalahan dan penentuan solusi yang ditawarkan dan disepakati bersama mitra.

3) Penyusunan materi dan kelengkapan kegiatan 
b. Tahap pelaksanaan diklat dan penyuluhan, meliputi:

1) Teknologi pengolahan stik wortel, stik ubi ungu, makaroni ebi dan makaroni ubi, dari mulai penyiapan bahan baku hingga pengemasan dan analisis daya terima konsumen (Anonim, 2012).

2) Perancangan desain kemasan stik wortel, stik ubi ungu, makaroni ebi dan makaroni ubi yang sesuai dengan standar minimal kemasan produk pangan (Effendi, 2009).

3) Pemberian bantuan berupa peralatan pengolahan untuk mendukung proses pengolahan yang lebih efektif dan optimal.

4) Perancangan merk dan kemasan yang menarik serta memasarkan dengan jaringan yang luas (Kotler dan Gary, 2013; Kotler dan Kevin, 2013).

c. Metode Pelatihan

Untuk melaksanakan kegiatan tersebut digunakan beberapa metode pelatihan yaitu :

1) Metode ceramah: metode ini memberikan penjelasan mengenai materi pelatihan dan memotivasi anggota kelompok agar memiliki ketetampilan dan keahlian di bidang pembentukan industri kecil khususnya pengolahan pangan.

2) Metode tanya jawab: metode tanya jawab sangat penting dapat mengukur peserta pelatihan dapat menerima penjelasan dan materi yang diberikan.

3) Metode aplikasi: metode aplikasi proses pengolahan makanan ringan stik wortel, stik ubi ungu, makaroni ebi dan makaroni ubi dilakukan melalui praktik proses pengolahan.

\section{HASIL DAN PEMBAHASAN}

\section{Pembentukan Industri Rumah Tangga}

Menurut UU No.5 Tahun 1984 dalam Kartasapoetra (2000), industri adalah kegiatan ekonomi yang mengolah bahan mentah, bahan baku, barang setengah jadi dan atau barang jadi menjadi barang dengan nilai yang lebih tinggi lagi penggunaannya, termasuk kegiatan rancang bangun industri dan perekayasaan industri. Dalam kegiatan pengabdian kepada masyarakat ini, proses pembentukan industri rumah tangga dilakukan dengan tujuan untuk memberdayakan kelompok perempuan yang telah terbentuk di Desa Bukit Peninjauan II dan Desa Sido Luhur sehingga bisa melakukan kegiatan ekonomi. Pemilihan jenis usaha dilakukan berdasarkan hasil diskusi dan kesepakatan bersama antara tim IbM dan mitra, yaitu terbentuknya sebuah industri kecil yang dikelola oleh kelompok perempuan Mawar Melati dan Mandiri Jaya, di bidang pengolahan stik wortel, stik ubi ungu, makaroni ubi dan makaroni ebi. Melalui diskusi kelompok yang dimediasi oleh tim IbM, terbentuklah nama industri untuk masing-masing kelompok. Secara rinci, spesifikasi usaha yang dirintis disajikan dalam Tabel 1.

Tabel 1. Spesifikasi Jenis Usaha Kelompok Perempuan

\begin{tabular}{llll}
\hline Nama Kelompok & \multicolumn{1}{c}{ Produk } & Merk Dagang/ Nama Industri & \multicolumn{1}{c}{ Lokasi Usaha } \\
\hline Mawar Melati & Stik wortel & Mawar Melati & Desa Bukit \\
& Stik ubi ungu & & Peninjauan II \\
& Makaroni ubi ungu & & \\
& Makaroni ebi & & Desa Sido Luhur \\
\hline Mandiri Jaya & Stik wortel & Bintang Rafflesia & \\
& Stik ubi ungu & & \\
& Makaroni ubi ungu & & \\
& Makaroni ebi & & \\
\hline
\end{tabular}




\section{Penyuluhan dan Diklat Teknologi Pengolahan}

Demi menjaga efektifitas dan tercapainya tujuan, pelaksanaan penyuluhan dilakukan secara terpisah antara kelompok perempuan Mawar Melati dan Mandiri Jaya. Respon dan antusiasme anggota kelompok sangat tinggi, terlihat dari jumlah peserta penyuluhan yang mencapai 21 dan 22 orang per kelompok. Kegiatan penyuluhan dan diklat ditampilkan pada Gambar 1.
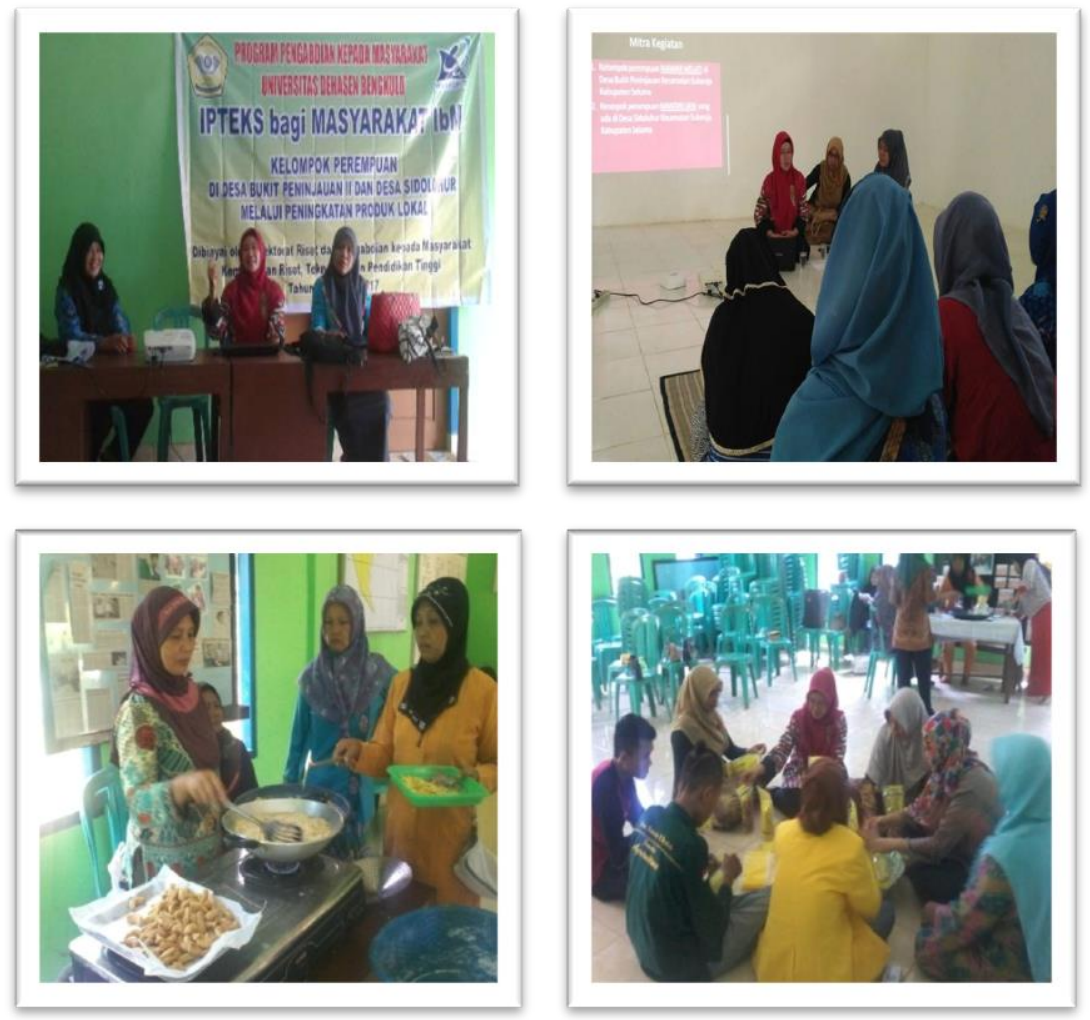

Gambar 1. Kegiatan penyuluhan dan diklat

Kegiatan penyuluhan melibatkan mahasiswa (pembagian tugas seperti pada Tabel 2) sebagai pelaksana praktik pengolahan, meliputi proses pengolahan stik wortel, stik ubi ungu, makaroni ubi ungu dan makaroni ebi. Produk olahan yang dihasilkan disajikan pada Gambar 2.

Tabel 2. Pembagian Tugas Kegiatan Penyuluhan dan Diklat Teknologi Pengolahan

\begin{tabular}{cllll}
\hline $\begin{array}{c}\text { Nama } \\
\text { Kelompok }\end{array}$ & \multicolumn{1}{c}{ Desa } & \multicolumn{1}{c}{$\begin{array}{c}\text { Koordinator } \\
\text { Pelaksana }\end{array}$} & \multicolumn{1}{c}{ Nama Mahasiswa } & \multicolumn{1}{c}{$\begin{array}{c}\text { Kehadiran } \\
\text { Anggota }\end{array}$} \\
\hline Mawar Melati & Bukit & Lina Widawati, & Yuni Lestari & 22 orang \\
& Peninjauan II & STP., MP & $\begin{array}{l}\text { Rhena Puspita S } \\
\text { Wahyudi } \\
\text { Suci Rahma W }\end{array}$ & \\
& & & 1. Oci Ariska & 24 orang \\
Mandiri Jaya & Sido Luhur & Dewi Suranti, & 2. Ishar & \\
& & M.Kom & 3. Edy Saputra & \\
& & & 4. Devira Sonya M & \\
& & &
\end{tabular}



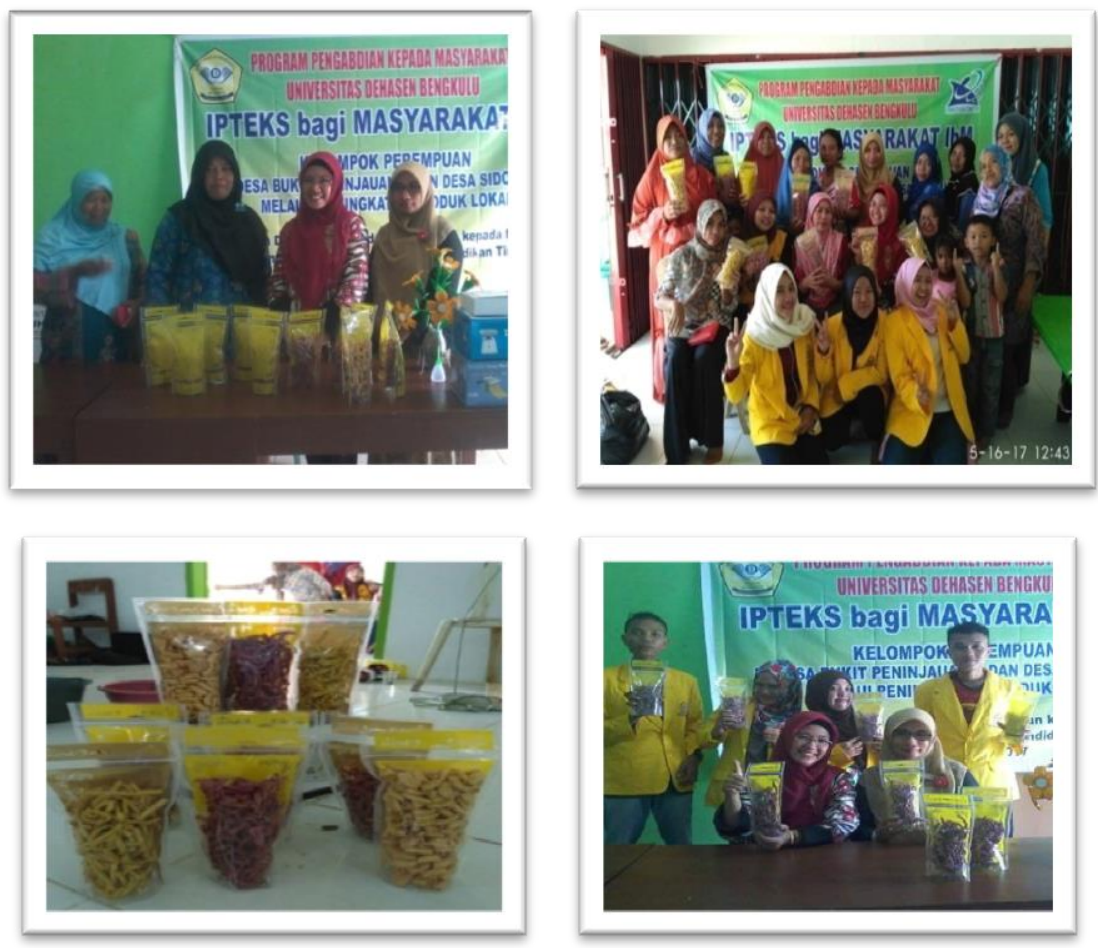

Gambar 2. Produk olahan kelompok perempuan

\section{Perancangan Desain Kemasan}

Proses perancangan desain kemasan dilakukan melalui diskusi antara tim dan kedua mitra, sehingga dicapai kesepakatan demi tercapainya efisiensi dan sesuai dengan tujuan. Untuk proses perancangan desain label kemasan, kedua mitra memberikan masukan mengenai informasi inti meliputi merk dagang, warna label, sementara tim dipercaya untuk mengembangkannya. Hasil proses perancangan desain kemasan secara rinci dijelaskan pada Tabel 3, sedangkan tampilan kemasan dan label produk disajikan pada Gambar 3.

Tabel 3. Spesifikasi Kemasan dan Label Produk

\begin{tabular}{clll}
\hline $\begin{array}{c}\text { Nama } \\
\text { Kelompok }\end{array}$ & $\begin{array}{l}\text { Merk Dagang/ } \\
\text { Nama Industri }\end{array}$ & \multicolumn{1}{c}{ Jenis Kemasan } & \multicolumn{1}{c}{ Ciri Khas } \\
\hline Mawar Melati & Mawar Melati & $\begin{array}{l}\text { Plastik berbentuk } \\
\text { "pouch" berperekat }\end{array}$ & $\begin{array}{l}\text { Label bergambar bunga } \\
\text { mawar } \\
\text { Kemasan bermotif pada satu } \\
\text { sisi }\end{array}$ \\
\hline Mandiri Jaya & Bintang & $\begin{array}{l}\text { Plastik berbentuk } \\
\text { "pouch" berperekat }\end{array}$ & $\begin{array}{l}\text { Label bergambar bunga } \\
\text { raflesia } \\
\text { Kemasan polos pada satu } \\
\text { sisi }\end{array}$ \\
\hline
\end{tabular}



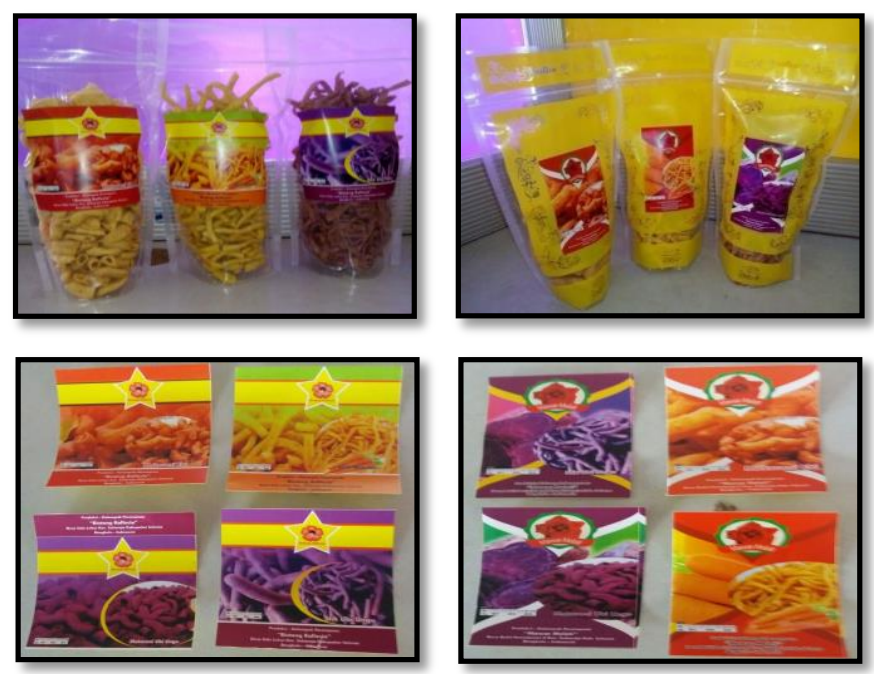

Gambar 3. Tampilan kemasan dan label produk

\section{Pemberian Bantuan Peralatan Produksi dan Sarana Usaha}

Untuk mencapai tujuan utama dalam kegiatan pengabdian masyarakat, yaitu terbentuknya suatu usaha kecil yang dikelola oleh kelompok perempuan, maka tim memberikan bantuan berupa mesin dan peralatan serta sarana usaha lainnya. Peralatan dan sarana usaha yang diberikan adalah peralatan inti yang diperlukan untuk kelancaran proses produksi dan pendukung kegiatan pemasaran, yang terdiri dari :
a. Mesin pencetak "pasta maker/ concerto"
h. Blender
i. Plastic sealer
b. Spinner
c. Kompor gas
j. Etalase untuk display produk
d. Tabung gas
e. Kuali
f. Pencetak mie "ampia"
g. Timbangan
k. Spanduk etalase
1. Kemasan dan label sebagai modal awal
m. Peralatan lainnya
Pemberian bantuan mesin dan peralatan tersebut disertai dengan sosialisasi cara penggunaannya, seperti ditampilkan pada Gambar 4 dan 5 .
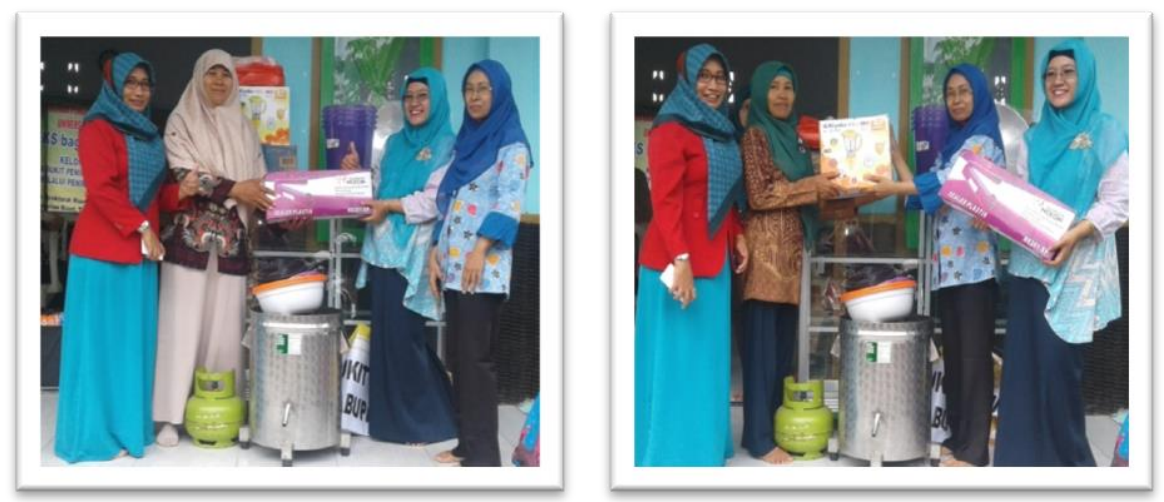

Gambar 4. Penyerahan bantuan mesin dan peralatan produksi 

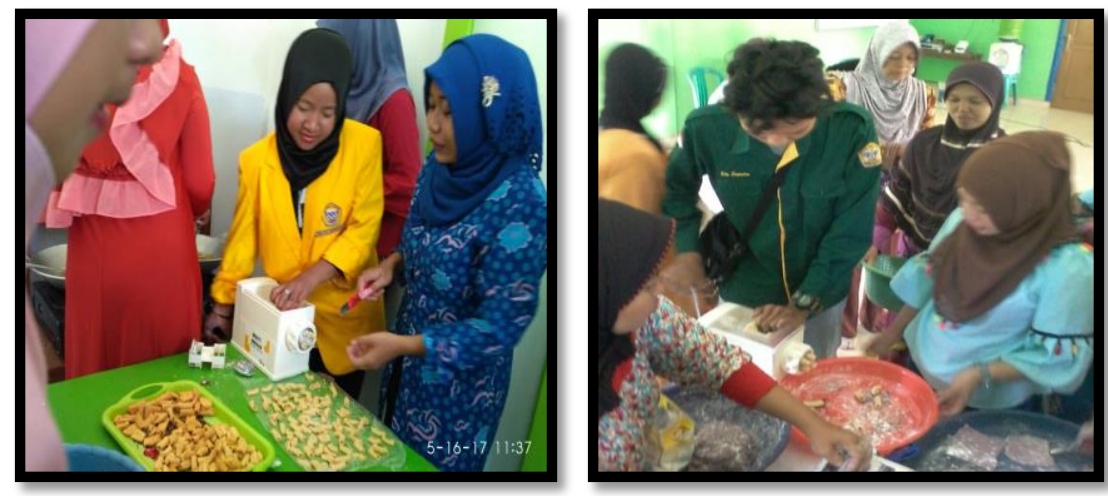

Gambar 5. Sosialisasi penggunaan mesin dan peralatan

\section{KESIMPULAN DAN SARAN}

\section{Kesimpulan}

Berdasarkan kegiatan pengabdian kepada masyarakat yang telah dilakukan, dapat diambil kesimpulan bahwa, kelompok perempuan Mawar Melati dan Mandiri Jaya yang berada di Desa Bukit Peninjauan II dan Desa Sido Luhur mempunyai potensi yang cukup besar melakukan kegiatan ekonomi di bidang pengolahan pangan. Telah terbentuk usaha kecil di bidang pengolahan stik wortel, stike ubi ungu, makaroni ubi dan makaroni ebi yang dikelola oleh kelompok perempuan Mawar Melati dengan merk dagang Mawar Melati, dan kelompok perempuan Mandiri Jaya dengan merk dagang Bintang Rafflesia.

\section{Saran}

Perlu dilakukan pembinaan lebih lanjut mengenai manajemen pengelolaan industri kecil demi menjaga keberlanjutan usaha yang telah terbentuk.

\section{UCAPAN TERIMA KASIH}

Ucapan terima kasih kami sampaikan kepada Direktorat Riset dan Pengabdian kepada Masyarakat Kemenristek Dikti yang telah memberikan dana kegiatan pengabdian kepada masyarakat melalui Program Hibah Ipteks bagi Masyarakat (IbM) untuk pendanaan Tahun 2017.

\section{DAFTAR PUSTAKA}

Anonim, 2012, Stik Ubi Ungu, http://anekakeripikmalang.com/2012/03/, diakses tanggal 10 April 2015.

Effendi, S, 2009, Teknologi Pengolahan dan Pengawetan Pangan, Alfabeta, Bandung.

Kartasapoetra, G, 2000, Makro Ekonomi, Edisi Kedua. Cetakan Keempat Belas, Raja Grafindo Persada, Jakarta. 
102 Dharma Raflesia Unib Tahun XV, Nomor 2 Desember 2017

Kotler, Phillip dan Kevin Lane Keller, 2013, Manajemen Pemasaran, Edisi 13, jilid 1, Erlangga, Jakarta.

Kotler, Philip dan Gary Armstrong, 2013, Prinsip-prinsip Pemasaran, Edisi 12, jilid 1, Erlangga, Jakarta.

Rachmat, M, 2017, Perspektif Pengembangan Industri Pengolahan Pangan di Indonesia, www.litbang.pertanian.go.id/buku/...pangan.

Sofia, R.N., 2014, Peran Perempuan dalam Keluarga Islami, http://staff.ugm.ac.id, diakses tanggal 10 April 2015. 